Article

\title{
(Un)supported Current Tourism Development in UNESCO Protected Site: The Case of Old City of Dubrovnik
}

\author{
Ivana Pavlić, Ana Portolan * and Barbara Puh \\ Department of Economics and Business Economics, University of Dubrovnik, Lapadska obala 7, \\ 20000 Dubrovnik, Croatia; ipavlic@unidu.hr (I.P.); barbara.puh@unidu.hr (B.P.) \\ * Correspondence: ana.portolan@unidu.hr; Tel.: +385-20-445923 \\ Academic Editor: Juan Ignacio Pulido Fernández \\ Received: 9 December 2016; Accepted: 2 March 2017; Published: 7 March 2017
}

\begin{abstract}
The main purpose of this paper is to explore and determine perceptions of residents living in the United Nations Educational, Scientific and Cultural Organization (UNESCO) protected site Old City of Dubrovnik (OCD) towards tourism development. Uncontrolled tourism expansion has impact on local residents' life and on their (un)support for specific form of tourism development. Comprehension of residents' perceptions is crucial for realization of adequate tourism development and for mutual satisfaction of tourism demand and supply. Therefore, the aim is to test the model of residents' perceptions of economic, socio-cultural and environmental impacts of tourism on their (un)support for specific form of tourism development. To realize the purpose of this research, Cronbach alpha, explorative (EFC) and confirmatory (CFA) factor analysis, and structural equation modeling (SEM) were applied. The findings indicate that there is a direct relationship between residents who perceive positive and negative economic, socio-cultural and environmental impacts of tourism and their (un)support for tourism development. This paper points out the role and significance of the permanent residents' perceptions research concerning the issues that are related to the quality tourism development due to the high interaction between local residents, tourists and local tourism development especially in the areas under the protection of UNESCO.
\end{abstract}

Keywords: local resident' perceptions; tourism development; UNESCO protected site; Old City Dubrovnik (OCD); tourism impacts

JEL Classification: Z32; M31

\section{Introduction}

Tourism is characterized by a high level of connectivity and interaction between residents and travelers (tourists, visitors and excursionists) that indicates importance of residents' attitudes researches. Negative residents' attitudes can jeopardize properly planned and high quality tourism growth while positive attitudes generate positive atmosphere for tourists and ensure sustainable long term tourism development. Therefore, it is not surprising that researches about residents' attitudes of tourism impacts are one of the main topics among tourism scholars.

Understanding residents' attitudes is essential for high quality sustainable tourism development and proper tourism destination management, especially in sites that are under the protection of United Nations Educational, Scientific and Cultural Organization (UNESCO).

The Republic of Croatia is located in southeastern Europe and covers the area of $87,661 \mathrm{~km}^{2}$. Today seven historical and one natural site are listed under the World Heritage List, while 17 more sites are tentatively listed. 
Dubrovnik is small city situated on the Croatian southern coast of the Adriatic Sea and is one of the most prominent Mediterranean destinations with 28,434 inhabitants [1]. Due its historical heritage and cultural value, Dubrovnik has unique comparative advantage and great potential for developing cultural tourism as special form of tourism. Dubrovnik highly depends on tourism with over 0.79 million tourist arrivals in 2015, over 0.86 million visitors from cruise ships and high number of excursionists, with a tendency of further growth. In total, 176,000 tourists and 140,000 visitors from cruise ships were in Dubrovnik in August 2015, eleven times more than people living there [1,2]. The number of excursionists visiting Dubrovnik is not included due to the data inexistence but it should be emphasized that this number would increase total number of passenger arrivals and passenger/residents ratio.

Old City of Dubrovnik —within the city walls (OCD)—gained World Heritage Status on the 3rd session of the World Heritage Committee meeting in October 1979 in Egypt as a first cultural urban and architectural complex in Republic of Croatia. The property was extended in 1994 on 18th session of the Committee and included areas outside the city walls, namely the Pile medieval industrial suburb, the Lovrijenac Fortress located on a cliff, the Lazarets (built in the early 17th century to house potential plague-carriers from abroad), Kaše moles (built to protect the port against southeasterly gales), the Revelin Fortress and island of Lokrum [3]. As part of Dubrovnik, it is a multiple use protected area which extends 94 hectares with buffer zone that covers additional 54 hectares. Currently, about 1000 permanently inhabited residents live in OCD which is less than $4 \%$ of total population in Dubrovnik.

OCD is arguably Dubrovnik's most visited attraction with more than one million visits annually. Presence of high number of tourists, visitors from cruise ships and excursionists has strong impact on local residents and their attitudes towards tourism. In spite of the above mentioned importance of tourism to Dubrovnik and the knowledge about importance of residents' attitudes, little is known about local community perceptions of tourism impacts in Dubrovnik.

OCD has been chosen for this research due to the facts it has been continuously inhabited from the ancient time, at the moment is considered to be included on the List of World Heritage in Danger due to the high number of travelers (tourists, visitors from the cruise ships and excursionists) and there has not been any scientific paper researching local residents' attitudes in OCD. This paper, therefore, is focused on attitudes of residents in OCD towards economic, socio-cultural and environmental impacts of tourism and on their (un)support for current mass, uncontrolled, unsegmented and unsustainable tourism development (CTD) or for special interest tourism development (SITD) focused on culture. Ensuring local residents' support for one of the tourism development forms in OCD is fundamental for sustainability, integrity and protection of the site.

The purpose of this paper was to explore attitudes from inhabitants of OCD in order to gain better understanding of the factors that influence their (un)support for one of the tourism development forms. The factors include perceived positive and negative economic, socio-cultural and environmental attitudes and connection with tourism development. Conceptual model with hypothesized relationships among variables was developed and tested.

There have been a number of studies focused on local residents' attitudes in World Heritage Sites [4-14], but there has not been any research dealing with local residents' attitudes towards different forms of tourism development (CTD and SITD). Therefore, this paper could be potentially valuable for those researchers who explore local residents' attitudes toward special interest tourism development generally and in World Heritage Sites.

\section{Literature Review}

\subsection{Residents' Attitudes towards Tourism Development}

Understanding residents' attitudes toward tourism impacts is relevant for accomplishing the adequate level of life quality that directly implicates local community's support for tourism development. Since local residents are the main stakeholders of tourism development in a 
destination [15], and their perceptions of tourism development are very important in evaluating the current situation towards the destination [16], it is not surprising that the number of studies on local community attitudes towards future tourism development has increased in the past decade and have reached 140 by year 2010 [17].

Since the beginning of 1970s, many studies have analyzed residents' attitudes and perceptions toward tourism development. In the beginning only positive effects of tourism development have been pointed out and later the attention was drawn on investigating local residents' attitudes on various impacts of tourism. Pizam [18] and Rotham [19] highlighted the importance of such studies in order to provide a solid base for high quality development of tourism to mutual satisfaction of both residents and tourists.

Brougham and Butler [20] found significant differences in residents' attitudes to the social impact of tourism with personal and location characteristics, length of residence, age and language being major explanatory variables. The research of Davis, Allen and Cosenza [21] in Florida showed there are five clusters of local residents with differing degrees of attitudes towards state's tourism efforts and pointed out the need to enlighten the residents about positive multiplier effects of tourism. A year later, Dogan [22] investigated sociocultural impacts of tourism. He found that in every destination/community groups of residents with different interests and responses to tourism emerge as a result of tourism development.

In the research in ten towns in New Zealand, Williams and Lawson [23] segmented local residents into four distinct opinion groups using cluster analysis. They found that those least in favor rated community oriented issues to be of greater importance than did other residents. Besculides, Lee and McCormick [24] used benefit based approach to examine the perceptions of cultural tourism by Hispanic and non-Hispanic residents in southern Colorado. They found that Hispanic residents showed greater concern for preservation of distinct cultural atmosphere than did non-Hispanic residents. In the research of Andriotis and Vaughan [25] in Crete using cluster analysis the authors discovered three clusters of residents regarding their attitudes toward tourism development. Education and employment in tourism were found to be the major factors affecting the attitudes of residents. Jackson and Inbakaran [26] investigated the link between positive and negative attitudes and residents' intentions to act towards tourism development in Regional Victoria, Australia. The research pointed out significant relationship between support for future development and gender, age, education, life cycle, length of residence and tourism business connection. However, research found no significant relationship between negative intentions to act (protest) and demographics as well as attitudes of various community cluster groups.

Chen and Chen [27] investigated the interrelationships between community attachment, economic dependence on tourism, perceived positive and negative impacts, and support for tourism development using SEM technique in southern Taiwan. The results indicated that community attachment and economic dependence on tourism have significant influence on positive tourism impact and can affect the support for tourism development. Stylidis et al. [28] investigated the role of residents' place image and perceived tourism impacts on their support for tourism development. They found that more favorable perceptions of the economic, socio-cultural and environmental impacts lead to greater support and that there is a positive relationship between residents' place image and their support for tourism development. Vargas Sanchez et al. [29] explored seasonality and its influence on the attitudes toward tourism development. The results showed that in low season the effects of tourism are perceived more favorably then in high season, leading to more positive attitudes toward further tourism development. In the research of Sinclair-Maragh, Gursoy and Vieregge [30] in two communities in Turkey, using factor-cluster analysis approach, authors found four groups of residents based on their perceptions of the impact of tourism development to their community and explained the differences between them.

Bagri and Kala [31] investigated residents' attitudes toward tourism impacts and influence of demographic attributes on their attitude. The study revealed that perceived impacts of tourism vary 
across residents' demographic variables. Sinclair-Maragh and Gursoy [32] in the conceptual model of residents' support for tourism development in developing countries discovered that there is a direct and significant relationship between residents' perceptions of the positive and negative impacts of tourism (economic, social, cultural and environmental) and their support for tourism development.

\subsection{Residents' Attitudes toward Tourism Development in World Heritage Sites}

It can be argued that World Heritage designation yields significant increases in proportions of international visitors to individual sites [4]. It is recognized that increasing number of visits to a specific site implicates the existence of conflict between heritage protection and tourism development, e.g., the issue of the sustainability of tourism development at this sites [5]. In the research of $\mathrm{Li}, \mathrm{Wu}$, and Cai [5] in China, authors discovered three major sources of threat that may compromise the protection of heritage site: population pressure, development policies of local economies and lack of financial support for heritage sites.

Zamani-Farahani and Musa [6] explored residents' attitudes in Masooleh, a protected national heritage town in Iran, and found that local residents strongly support further tourism development. However, the research implicated that local residents are not satisfied with decision making by regional tourism authorities which denotes the need for inclusion of residents in future tourism planning. Nicholas et al. [7] examined the factors that influence local residents' support for sustainable tourism development in the Piton Management Area, St. Lucia. The results from structural equation modeling showed that environmental attitudes indirectly influenced the support for sustainable tourism development.

Okech [8] investigated the socio cultural impacts of tourism on World heritage sites in Kenya and Zanzibar Islands. She found that residents of both heritage sites have positive perceptions and attitudes toward local tourism development, due to the growth of employment and income, regardless of negative effects like cost of living, general prices for goods and services, noise, crime and congestion. Ryan, Chaozhi and Zeng [9] examined the residents' perceptions of the impact of tourism at UNESCO heritage site in China-Kaiping Diaolou, a destination in an early stage of tourism development. The research has shown that residents have positive attitudes about UNESCO designation of a World Heritage Site and about socio-cultural and economic effects tourism development has on their lives.

Long [10] investigated the support for tourism development in Ha Long Bay, Vietnam. The research results indicated that residents viewed tourism positively and would support further development because of the economic and socio-cultural benefits tourism provides. However, the research also showed that residents were slightly ambivalent to environmental impacts of tourism. Cruz Vereiro et al. [11] in the research made in Portugal used cluster analysis to separate Guimaraes residents into clusters according to their perceptions of the impact of tourism development. They found three clusters: the skeptics, the moderately optimistic and enthusiasts. In the research made by Kalterborg et al. [12] in Vega, central Norway, the authors examined the local population views of the future tourism development as well as the level of relation to World Heritage Site. They found that majority of residents supported tourism based on sustainable use of heritage, but also that residents feel World Heritage listing should not limit development opportunities. In addition, differences in attitudes were found among different age groups.

$\mathrm{Su}$ and Wall [13] investigated community participation in tourism at a World Heritage Site at Mutianyu Great Wall, China. They found that residents have positive perceptions towards World Heritage, tourism development and tourism economic, social, cultural and environmental impacts. Differences between groups indicated that local opinions are influenced by different levels of impact and participation in tourism. Vereiro and Mendes [14] examined residents' perspectives of the importance of the World Heritage Site classification of historic centers Angra do Heroismo and Evora and perceived tourism impacts on Portuguese World Heritage. The results indicated that local residents have a strong positive perception of the World Heritage Site designation in both municipalities. Regarding perceived tourism effects, residents from Angra de Heroismo have a stronger 
agreement about the impacts of tourism on their city, than the residents of Evora, except for the negative ones.

\section{Methodology}

Based on above mentioned literature review of residents' attitudes towards tourism development and especially of residents' attitudes toward tourism development in World heritage sites, an integrated model that includes perceived positive and negative economic, socio-cultural and environmental impact of tourism; personal connection to tourism industry and finally support for current tourism development (CTD) or special interests tourism development (SITD), is depicted in Figure 1. Concept current tourism development (CTD) implies current mass, unsegmented, unsustainable and uncontrolled tourism development, while special interests tourism development (SITD) refers to special interest of tourism with culture as primary travel motive. Specifically, support of tourism development is hypothesized to be the consequence of the residents' perceptions of tourism impacts related to their connection to tourism industry.

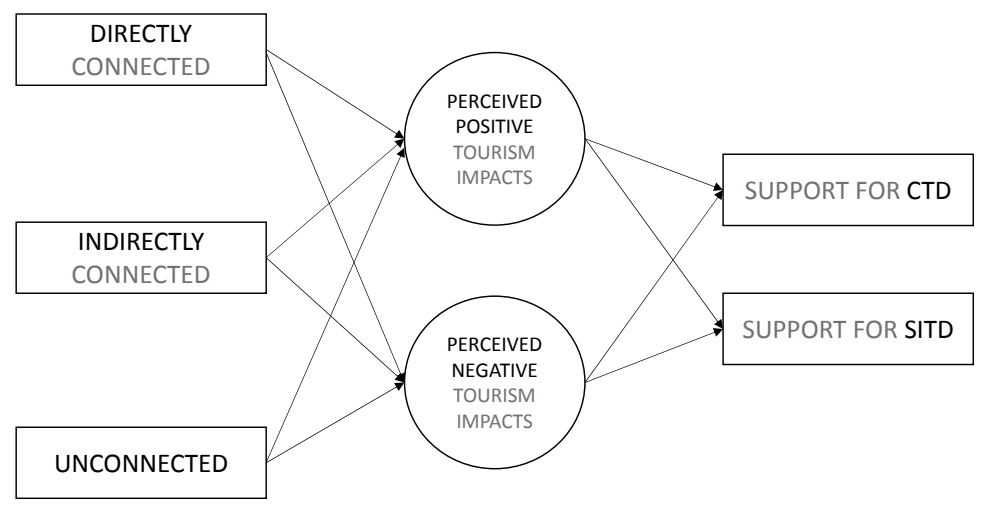

Figure 1. The integrated model of residents' support for the CTD or SITD in UNESCO protected site.

\subsection{Sample and Data Analysis}

In order to analyze the situation in the UNESCO protected site, Old City of Dubrovnik (within the city walls), and to develop a model, empirical research was carried out using a sample survey taken from 376 convenience-chosen local residents in Old City of Dubrovnik. The research was carried out from 1 May 2015 to 1 May 2016. In total, 208 questionnaires were administered personally to the respondents. The sample profile is summarized in Table 1. To realize the purpose of this research, explorative (EFC) and confirmatory factor analysis (CFA), and structural equation modeling (SEM) were applied. These methods were used because they are the established methods accepted within the field.

A high structured questionnaire, that included all constructs of the proposed model to test the below mentioned hypotheses, was used. The questions were based on the review of literature and the questionnaire consisted of four main parts. The items of this study were obtained by analyzing the available literature. The first part of questionnaire consists of items for measuring perceptions of residents towards positive and negative economic, socio-cultural and environmental tourism impacts that have been retrieved from different empirical studies [7,27,33,34].

Considering the obtained literature and regarding the particularly circumstances of tourism development in protected site, Old City of Dubrovnik (OCD), this study includes 36 items due to exclusion of exceptional and redundant items. These items were divided in two groups, namely positive (18 items: 8 economic, 7 socio-cultural and 3 environmental) and negative ones (18 items: 6 economic, 6 socio-cultural and 6 environmental items). The second part explored the connection of local resident to tourism industry (direct, indirect and without connection-manifest variables) and was measured by dichotomous questions (yes/no). The third part dealt with support for CTD 
or SITD using manifest variables. CTD was measured by dichotomous question "Do you support current mass, uncontrolled, unsegmented and unsustainable tourism development?" and SITD by dichotomous question "Do you support cultural special interest tourism development?" The base for using manifest variables for measurement of local residents' connection to tourism industry can be found in papers by Mazón, et al. [35] and Hanafiah [15] and for support for tourism development in papers by Untong et al. [36], Woosnam [37] and Choi [38]. The last part of questionnaire was focused on demographic variables (age, gender, level of education, occupation and monthly income) in order to create profile of survey respondents. Local residents' attitudes were measured applying 5-point Likert scale ranging from extremely negative to extremely positive.

First of all exploratory factor analysis (EFA) by principal components analysis method with varimax rotation (PCA) was applied on the data to determine the dimensionality of positive and negative tourism impacts constructs as the pre-test and initial data analysis. The first variable named "perceived positive impacts" was obtained using three variables: positive economic impacts in first sub-section with 8 items $(\alpha=0.851)$, the second sub-section obtained 7 items of positive socio-cultural tourism impacts $(\alpha=0.740)$ and the last sub-section obtained positive environmental tourism impacts -3 items $(\alpha=0.725)$. The second variable observed negative impacts of tourism and was specified with 18 items in total; negative economic impacts in first sub-section $(\alpha=0.702)$, negative socio-cultural tourism impacts in the second sub-section $(\alpha=0.850)$ and the negative environmental impacts in the last sub-section $(\alpha=0.782)$. The underlying factors derived from EFA were represented as correlations between sets of many interrelated variables. This method can help in decreasing error variance correlation between indicators in confirmatory factor analysis in the phase of measurement model. Data analysis continued with the tests of assumptions against sampling adequacy, multicollinearity and multivariate normality required for Confirmatory factor analysis (CFA). CFA with maximum likelihood estimation method was conducted to establish the reliability and validity by composite reliability (CR) which must be more than 0.70 to indicate that the measures are reliable.

The second stage, the evaluation of the goodness-of-fit guides for the proposed structural equation model and the testing hypothesis was accomplished. The results obtained from the survey were analyzed using different analytical tools, including methods of analysis and synthesis, inductive and deductive methods, method of generalization and specialization, and different statistical methods.

The aim of the research was to define the dependence of different relevant parameters with support of local resident for the CTD or SITD in the OCD as UNESCO protected site. Therefore, in order to determine the direction and significance of the relationships, the hypotheses were tested simultaneously. A variety of analytical tools were applied in the analysis, including EFA, CFA and path analysis which consider jointly all hypotheses put forward. Manifest variable is allowed to have nonzero loadings on the factors in the model. All statistical analyses were processed with the statistical package SPSS version 20.0 and AMOS.

\subsection{Research Hypotheses}

The general tourism impact consists of two constructs and has been defined as positive and negative ones. Each mentioned construct consisted of three components (economic, socio-cultural and environmental). According to the above-mentioned theoretically accepted knowledge, it is assumed that perceived positive and negative economic, socio-cultural and environmental tourism impacts are related to different levels of connection to tourism industry and local residents' support for the CTD or SITD. Their acceptability will be tested on local residents' support for the tourism development in the UNESCO protected site, Old City of Dubrovnik (OCD), as a tourist destination using the following hypotheses:

H1: Residents who are directly connected to tourism industry perceive positive tourism impacts and support CTD over SITD. 
H2: Residents who are indirectly connected to tourism industry perceive more positive than negative tourism impacts and support CTD over SITD.

H3: Residents who are not connected to tourism industry perceive more negative than positive tourism impacts and support SITD over CTD.

\section{Results and Discussion}

The results of the descriptive statistics indicated respondents' profiles. Approximately $64.2 \%$ of the respondents were female and $35.8 \%$ were male. The age groups were represented as follows: $25.7 \%$ from 18 to $34,50.8 \%$ from 35 to $49,19.6 \%$ from 50 to 64 , and $3.9 \%$ from 65 . In other words, $76.5 \%$ were young and middle aged people (18 to 50 years old). The education structure showed that all respondents completed high school and higher education, indicating that a large proportion of the sample was well educated (44.6\% have undergraduate and graduate education). In total, $29.6 \%$ of residents worked in private sector. The majority of the respondents, $92.2 \%$, had monthly incomes under 8001 croatian kunas ( 1 croatian kuna $(1 \mathrm{HRK})=0.13$ euros). Table 1 shows the respondents' profile.

Table 1. Respondents' profile.

\begin{tabular}{|c|c|c|}
\hline Demographic characteristics & Frequency & Percentage $(\%)$ \\
\hline \multicolumn{3}{|l|}{ Age } \\
\hline $18-34$ & 53 & 25.7 \\
\hline $35-49$ & 106 & 50.8 \\
\hline $50-64$ & 41 & 19.6 \\
\hline 65 and over & 8 & 3.9 \\
\hline \multicolumn{3}{|l|}{ Gender } \\
\hline Male & 75 & 35.8 \\
\hline Female & 133 & 64.2 \\
\hline \multicolumn{3}{|l|}{ Education } \\
\hline High school and less & 78 & 37.5 \\
\hline Undergraduate and graduate & 111 & 53.4 \\
\hline Postgraduate & 19 & 9.1 \\
\hline \multicolumn{3}{|l|}{ Occupation } \\
\hline Public sector & 44 & 20.7 \\
\hline Private sector & 61 & 29.6 \\
\hline Private businessman & 19 & 9.5 \\
\hline Housekeeper & 5 & 2.2 \\
\hline Student & 30 & 14.5 \\
\hline Retired & 14 & 6.7 \\
\hline Unemployed & 28 & 13.4 \\
\hline Other & 7 & 3.4 \\
\hline \multicolumn{3}{|l|}{ Monthly income in HRK* } \\
\hline under 3000 & 95 & 45.8 \\
\hline $3001-4000$ & 27 & 12.8 \\
\hline $4001-6000$ & 43 & 20.7 \\
\hline $6001-8000$ & 27 & 12.8 \\
\hline $8001-10,000$ & 10 & 5.0 \\
\hline $10,001-$ & 6 & 2.8 \\
\hline
\end{tabular}

* 1 HRK $=0.13 €$, Source: Authors' research.

Prior to implementing the confirmatory factor analysis, an evaluation was made with regard to the suitability of the data for a factor analysis. Reliability for each factor was obtained using the calculation for Cronbach's alpha coefficient (Table 2). Considering Peterson [39] suggested that the value of Cronbach's alpha of 0.6 is criterion in use, all analyzed factors are acceptably reliable. 
Table 2. EFA of positive and negative tourism impact.

\begin{tabular}{|c|c|c|c|c|}
\hline Variables & $\begin{array}{c}\text { Factor } \\
\text { Loading }\end{array}$ & $\begin{array}{c}\text { Cronbach's } \\
\text { Alpha }\end{array}$ & KMO & Bartlett \\
\hline \multicolumn{5}{|l|}{ Positive Impacts of Tourism } \\
\hline Tourism has increased job opportunities & 0.564 & & & \\
\hline Tourism has increased entrepreneurial opportunities & 0.674 & & & \\
\hline Tourism has increased foreign investment & 0.749 & & & \\
\hline Tourism has given economic benefits to small crafts (businesses) & 0.697 & & & \\
\hline Tourism has increase revenue to the firms directly connected to tourism & 0.609 & & & \\
\hline Tourism has increase revenue to the firms indirectly connected to tourism & 0.687 & & & \\
\hline Positive socio-cultural impacts & & 0.740 & 0.697 & 0.000 \\
\hline Tourism has encouraged residents' participation in cultural activities & 0.612 & & & \\
\hline Tourism has increased entertainment offer & 0.749 & & & \\
\hline Positive environmental impacts & & 0.725 & 0.500 & 0.000 \\
\hline Tourism has raised more awareness of protection for natural resources & 0.786 & & & \\
\hline Tourism has raised more awareness of protection for cultural resources & 0.786 & & & \\
\hline Tourism has increased local recreational facilities and resources & 0.726 & & & \\
\hline \multicolumn{5}{|l|}{ Negative Impacts of Tourism } \\
\hline Negative economic impacts & & 0.702 & 0.693 & 0.000 \\
\hline Tourism brings more costs than benefits to the local people & 0.592 & & & \\
\hline Tourism stimulate offer more of import than local products & 0.580 & & & \\
\hline Foreign tourism firms has more benefits than local tourism firms & 0.688 & & & \\
\hline Tourism has raised local products prices & 0.606 & & & \\
\hline Tourism has increased residents' living costs & 0.782 & & & \\
\hline Negative environmental impacts & & 0.782 & 0.738 & 0.000 \\
\hline Tourism development is uncontrolled & 0.663 & & & \\
\hline Tourism has caused more traffic problems & 0.666 & & & \\
\hline Tourism cause overcrowding problems for residents & 0.601 & & & \\
\hline Tourism has increased the level of sea pollution & 0.648 & & & \\
\hline Tourism has increased the level of air pollution & 0.643 & & & \\
\hline Tourism has increased litter in an area & 0.603 & & & \\
\hline
\end{tabular}

Source: Authors' research.

An examination of the correlation matrix in EFA showed that all of the coefficients were over 0.4 . The KMO value was over 0.5 for all analyzed indicators. The Bartlet test for all elements achieved statistical significance (Table 2). Therefore, null hypothesis was rejected which means that correlation matrix was an identity matrix and that variables were correlated highly enough to provide a reasonable basis for factor analysis. This confirms the fact that there is a good interrelationship between study items and also indicates factorability of the analyzed correlation matrixes. In addition, the absolute values of correlation coefficients between the factors are lower than 0.850 , which confirms that measurement scales exhibit discriminant validity [40].

In the second stage, CFA was applied for the further verification and confirmation of the convergent and discriminant validity of the new constructs. Confirmatory model including all researched impacts (variables) was developed and also tested. The manifest variables were used to measure residents connection (direct, indirect or without connection) to tourism industry and support for the CTD or SITD in the OCD, and latent were constructs-positive and negative economic, socio-cultural and environmental tourism impacts. The applied measurement model assumed that every manifest variable loads on one construct (latent variable/impact) and that factors are correlated. Therefore, to test the unidimensionality of measurement scales, the independence of measurement 
errors was presumed, along with manifest variable loading on one factor. Bearing in mind the analyzed literature in the terms of the cut-off points for fit values, CFA shows that measurement model fits data well $(p=0.000 ;$ RMSEA = 0.059; GFI = 0.903; $\mathrm{AGFI}=0.892$; $\mathrm{NFI}=0.895 ; \mathrm{NNFI}=0.910 ; \mathrm{CFI}=$ 0.905). Every fit indicator is satisfactory. Consequently, CFA confirmed that measurement scales show convergent and discriminant validity and the unidimensionality of the applied model.

In order to test all aforementioned hypotheses / integrated model, a path analysis was applied. According to Reisinger and Turner [41], path analysis may be preferable to conventional statistical methods, for example, where multiple regression is required to test for several dependent variables from the same test of independent variables simultaneously, particular if it is possible for one dependent variable to simultaneously cause another. Therefore, the purpose of this research is to explore the relationships between different pairs of variables as a whole in order to determine the direction and significance of these relationships. In order to test hypotheses, structural parameters have been estimated. The fit indices were used to assess model adequacy. These results $\left(p=0.000 ; \chi^{2} / \mathrm{df}=2.16\right.$; RMSEA $=0.063 ;$ GFI $=0.906 ;$ AGFI $=0.898 ; \mathrm{NFI}=0.899 ; \mathrm{NNFI}=0.900 ; \mathrm{CFI}=0.896$ ) indicate a well-fitting model, taking into the consideration the fact that $\chi^{2} / \mathrm{df}$ ratio is less than 5 which implies a reasonable fit between the proposed model and the data on which the model is constructed [40]. The other goodness-of-fit statistics indicated an acceptable level of model fitness for the structural modeling of the data. Table 3 shows the results of regression weight estimates of the path model.

Table 3. Results of regression weight estimates of the path model.

\begin{tabular}{|c|c|c|c|}
\hline Variables & SE & CR & * \\
\hline \multicolumn{4}{|l|}{ H1: Directly connected to tourism industry $\rightarrow$ Support for CTD } \\
\hline H1a: Directly connected to tourism industry $\rightarrow$ Positive economic impacts of tourism & 0.091 & 4.372 & \multirow{6}{*}{$\mathrm{S}$} \\
\hline H1b: Directly connected to tourism industry $\rightarrow$ Positive socio-cultural impacts of tourism & 0.074 & 3.345 & \\
\hline H1c: Directly connected to tourism industry $\rightarrow$ Positive environmental impacts of tourism & 0.077 & 2.019 & \\
\hline H1d: Directly connected to tourism industry $\rightarrow$ Negative economic impacts of tourism & 0.065 & 1.118 & \\
\hline H1e: Directly connected to tourism industry $\rightarrow$ Negative socio-cultural impacts of tourism & 0.068 & 0.823 & \\
\hline H1f: Directly connected to tourism industry $\rightarrow$ Negative environmental impacts of tourism & 0.071 & 0.635 & \\
\hline \multicolumn{4}{|l|}{ H2: Indirectly connected to tourism industry $\rightarrow$ Support for CTD } \\
\hline $\mathrm{H} 2 \mathrm{a}$ : Indirectly connected to tourism industry $\rightarrow$ Positive economic impacts of tourism & 0.118 & 3.647 & \multirow{6}{*}{ S } \\
\hline $\mathrm{H} 2 \mathrm{~b}$ : Indirectly connected to tourism industry $\rightarrow$ Positive socio-cultural impacts of tourism & 0.094 & 2.836 & \\
\hline H2c: Indirectly connected to tourism industry $\rightarrow$ Positive environmental impacts of tourism & 0.078 & 3.321 & \\
\hline $\mathrm{H} 2 \mathrm{~d}$ : Indirectly connected to tourism industry $\rightarrow$ Negative economic impacts of tourism & 0.081 & 0.947 & \\
\hline H2e: Indirectly connected to tourism industry $\rightarrow$ Negative socio-cultural impacts of tourism & 0.072 & 2.689 & \\
\hline H2f: Indirectly connected to tourism industry $\rightarrow$ Negative environmental impacts of tourism & 0.067 & 0.728 & \\
\hline \multicolumn{4}{|l|}{ H3: Unconnected to tourism industry $\rightarrow$ Support for SITD } \\
\hline H3a: Indirectly connected to tourism industry $\rightarrow$ ositive economic impacts of tourism & 0.043 & 1.955 & \multirow{6}{*}{$\mathrm{S}$} \\
\hline $\mathrm{H} 3 \mathrm{~b}$ : Indirectly connected to tourism industry $\rightarrow$ Positive socio-cultural impacts of tourism & 0.064 & 1.844 & \\
\hline H3c: Indirectly connected to tourism industry $\rightarrow$ Positive environmental impacts of tourism & 0.067 & 0.521 & \\
\hline H3d: Indirectly connected to tourism industry $\rightarrow$ Negative economic impacts of tourism & 0.112 & 4.365 & \\
\hline H3e: Indirectly connected to tourism industry $\rightarrow$ Negative socio-cultural impacts of tourism & 0.094 & 5.318 & \\
\hline H3f: Indirectly connected to tourism industry $\rightarrow$ Negative environmental impacts of tourism & 0.084 & 4.477 & \\
\hline
\end{tabular}

* $\mathrm{R}$ = rejected; $\mathrm{S}=$ Supported. Source: Authors' research

Table 3 displays standard error (SE) and the estimate divided by the standard error (Critical Ratio (CR) as well as supported and rejected hypotheses. Within the structural equation model, the estimates of the structural coefficient provide the basis for testing the proposed hypotheses. According to Table 3, all three hypotheses are confirmed in the estimated structural model, although some sub-hypotheses are rejected. Namely, residents who are directly connected to tourism industry perceive positive economic $(\gamma=0.47 ; t$-value $=4.12)$, socio-cultural $(\gamma=0.33$; $t$-value $=3.21)$ and environmental $(\gamma=0.19 ; t$-value $=2.11)$ impacts of tourism. Residents who are directly connected to tourism industry do not perceive negative economic $(\gamma=0.06$; $t$-value $=0.64)$, socio-cultural $(\gamma=0.07 ; t$-value $=0.71)$ or environmental $(\gamma=0.03 ; t$-value $=0.32)$ tourism impacts. Residents who perceive positive tourism impacts support CTD: those who perceive positive economic impacts 
support CTD $(\gamma=0.54 ; t$-value $=5.37)$ more than SITD $(\gamma=0.22 ; t$-value $=2.36)$; residents who perceive positive socio-cultural impacts also support more CTD $(\gamma=0.52 ; t$-value $=5.28)$ than SITD $(\gamma=0.20 ; t$-value $=2.13)$; and those who perceive positive environmental tourism impacts support more CTD $(\gamma=0.34 ; t$-value $=3.40)$ than SITD $(\gamma=0.03$; $t$-value $=0.38)$. This means that hypothesis one is supported.

Those residents who are indirectly connected to tourism industry also perceive positive economic $(\gamma=0.24 ; t$-value $=2.33)$, socio-cultural $(\gamma=0.21 ; t$-value $=2.19)$ and environmental $(\gamma=0.20$; $t$-value $=2.06)$ impacts of tourism. They also perceive negative socio-cultural impacts of tourism $(\gamma=0.19 ; t$-value $=2.01)$, but do not perceive negative economic $(\gamma=0.08 ; t$-value $=0.84)$ and environmental $(\gamma=0.04 ; t$-value $=0.47)$ tourism impacts. Residents who are indirectly connected to tourism industry also perceive more positive than negative tourism impacts, and are more conscious about negative socio-cultural tourism impacts than the previous group of residents. They also support CTD over SITD, which means hypothesis two is confirmed.

Finally, residents who are unconnected to tourism industry perceive positive economic $(\gamma=0.16$; $t$-value $=1.72)$ and socio-cultural impacts of tourism $(\gamma=0.18 ; t$-value $=1.91)$ but they do not perceive positive environmental impacts of tourism $(\gamma=0.08$; $t$-value $=0.83)$. They perceive more negative tourism impacts than positive: negative economic impacts of tourism $(\gamma=0.43$; $t$-value $=4.23)$, socio-cultural $(\gamma=0.47 ; t$-value $=4.68)$ and especially environmental tourism impacts $(\gamma=0.52$; $t$-value $=5.35)($ Figure 2$)$.

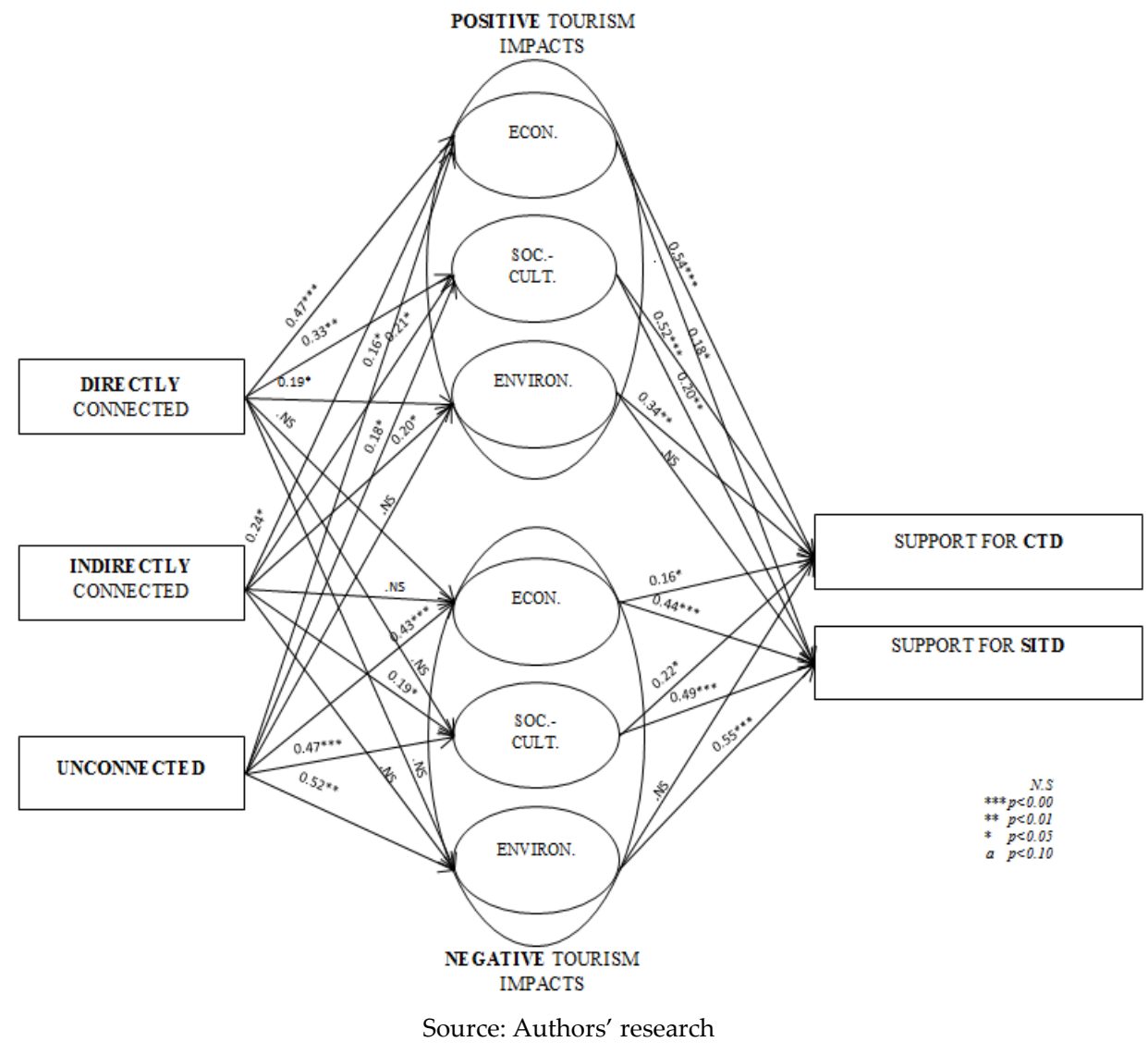

Figure 2. Model of Path Analysis of local residents' attitudes in OCD.

Residents who are unconnected to tourism industry perceive more negative than positive tourism impacts and support SITD: those who perceive negative economic impacts support SITD $(\gamma=0.44$; $t$-value $=4.39)$ over CTD $(\gamma=0.16$; $t$-value $=1.55)$; residents who perceive negative socio-cultural impacts also support SITD $(\gamma=0.48$; $t$-value $=4.82)$ over $\operatorname{CTD}(\gamma=0.17$; $t$-value $=1.67)$; and those who 
perceive negative environmental tourism impacts also support SITD $(\gamma=0.55 ; t$-value $=5.43)$ over CTD (not significant). This confirms the third hypothesis.

At the end it can be concluded that residents who are directly connected to tourism industry do not perceive any negative impacts of tourism (economic, socio-cultural or environmental) and support CTD over SITD due to their economic benefits from tourism. Residents who are indirectly connected to tourism industry perceive positive impacts of all components of tourism and only negative socio-cultural impacts, which implies they are more socio-cultural conscious than those directly connected to tourism industry. Regardless of their perception of negative socio-cultural impacts they also support CTD over SITD. Residents who are unconnected to tourism industry perceive more negative than positive tourism impacts and support SITD.

\section{Conclusions}

Tourism impacts are numerous and complex; include economic, socio-cultural and environmental components; and are visible in all tourism destination. These impacts are even more evident in UNESCO protected sites.

Through the literature review it can be concluded that there are number of scientific researches of perceived positive and negative tourism impacts, but researches of sites included on List of World Heritage in Danger and those considered to be included, have been neglected. In addition, the researches of local residents' attitudes in inhabited sites under the UNESCO protection are marginalized.

Since the quality of life of inhabitants living in OCD has been endangered by tourism impacts, the need for research and respect of their attitudes has emerged.

The main contribution of this paper is classification of OCD local residents in three groups, namely directly, indirectly and unconnected to tourism industry and usage of concepts "current tourism development" (CTD) and "special interests of tourism development" (SITD). The research results indicated that residents who are directly connected to tourism industry do not perceive negative economic, socio-cultural or environmental impacts of tourism and support CTD over SITD due to their economic benefits from tourism. Residents who are indirectly connected to tourism industry perceive positive impacts of all components of tourism and only negative socio-cultural impacts, which implies they are more socio-cultural conscious than those directly connected to tourism industry. Regardless of their perception of negative socio-cultural impacts they also support CTD over SITD. Residents who are unconnected to tourism industry perceive more negative than positive tourism impacts and support SITD. Other, but not less valuable contribution is fact that research has been conducted in a site that is inhabited, tourism developed and considered to be included on List of World Heritage in Danger due to the high number of travellers.

Even though they live in a UNESCO protected site and their way of living is compromised by large number of travelers (tourists, visitors from cruise ships and excursionists), residents connected to tourism industry (directly or indirectly) support CTD over SITD. Justification of that way of perception, where short term economic benefits are stronger than long term sustainable development, can be found in inadequate level of education towards disadvantages of short term economic thinking. Residents who are not connected to tourism industry showed higher level of awareness of negative tourism impacts compared to previous analyzed groups. This can be explained by the fact they do not have direct or indirect benefits from tourism what gave them different perspective. They have recognized the necessity of new approach for one of the tourism development forms which will protect OCD heritage site and their way of living in it.

According to everything mentioned above, it is necessary to develop management plan of protected heritage site OCD urgently; to raise local residents' awareness of the role and importance of sustainable tourism development with emphasize on heritage site protection, especially those living in OCD; and to control further tourism development through the continuous evaluation and monitoring, in order to protect and preserve cultural heritage for current and future generations. 
The main limitation of this research was the fact that research has been conducted in a period of one year, during high, low and out of the season which can affect local residents' attitudes, so it is likely to assume that out of season number of impacts would be perceived in a neutral manner. In addition, it can be alleged that in the period of higher number of travelers local residents would have different activities and perceived negative impacts would be higher in compare to the period with lower number of travelers. Since purposive sample has been used the outcomes of this research can be considered only as indicative. In addition, positive environmental impact variable was measured using only three statements, which can be seen as another limitation of this paper.

Further research should examine the role of different stage of season (high, low and out of season) as well as distance of place of living from OCD on local residents' attitudes towards tourism impacts.

Author Contributions: All authors participated equally in designing and collecting questionnaire, as well as in forming conceptual model tested in the paper. Barbara Puh reviewed literature connected with the title, Ana Portolan inserted data in SPSS programme and Ivana Pavlić analyzed those data. All authors participated in writing the introduction and conclusion remarks.

Conflicts of Interest: The authors declare no conflicts of interests.

\section{References}

1. Croatian Bureau of Statistics. Tourism in Seaside Resorts and Municipalities. 2015. Available online: www.dzs.hr (accessed on 16 July 2016).

2. Port of Dubrovnik. Available online: http://www.portdubrovnik.hr/girica1.php (accessed on 16 July 2016).

3. UNESCO. Report on the UNESCO-ICOMOS Reactive Mission to Old City of Dubrovnik, Croatia from 27 October to 1 November 2015. November 2015. Available online: whc.unesco.org/document/141053 (accessed on 3 March 2017).

4. Buckley, R. The Effects of World Heritage Listing on Tourism to Australian National Parks. J. Sustain. Tour. 2004, 12, 70-84. [CrossRef]

5. Li, M.; Wu, B.; Cai, L. Tourism Development of World Heritage Sites in China: A Geographic Perspective. Tour. Manag. 2008, 29, 308-319. [CrossRef]

6. Zamani-Farahani, H.; Musa, G. Residents' Attitudes and Perception towards Tourism Development: A Case Study of Masooleh, Iran. Tour. Manag. 2008, 29, 1233-1236. [CrossRef]

7. Nicholas, L.N.; Thapa, B.; Ko, Y.J. Residents' Perspectives of a World Heritage Site: The Piton Management Area, St. Lucia. Ann. Tour. Res. 2009, 36, 390-412. [CrossRef]

8. Okech, R.N. Socio-cultural Impacts of Tourism on World Heritage Sites: Communities' Perspectives of Lamu (Kenya) and Zanzibar Islands. Asia Pac. J. Tour. Res. 2010, 15, 339-351. [CrossRef]

9. Ryan, C.; Chaozhi, Z.; Zeng, D. The Impacts of Tourism at a UNESCO Heritage Site in China-A Need for a Meta-Narrative? The Case of Kaiping Diaolou. J. Sustain. Tour. 2011, 19, 747-765. [CrossRef]

10. Long, H. Tourism Impacts and Support for Tourism Development in Ha Long Bay, Vietnam: An Examination of Residents' Perceptions. Asian Soc. Sci. 2012, 8, 28-39. [CrossRef]

11. Da Cruz Vereiro, L.M.; Remoaldo, P.C.; Cadima Ribeiro, J.A. Residents' Perceptions of Tourism Impacts in Guimaraes (Portugal): A Cluster Analysis. Curr. Issues Tour. 2013, 16, 535-551. [CrossRef]

12. Kaltenborg, B. World Heritage Status as a Foundation for Building Local Futures? A Case Study from Vega in Central Norway. J. Sustain. Tour. 2013, 21, 99-116. [CrossRef]

13. Su, M.M.; Wall, G. Community Participation in Tourism at a World Heritage Site: Mutianyu Great Wall, Beijing, China. Int. J. Tour. Res. 2014, 16, 146-156. [CrossRef]

14. Vereiro, L.; Mendes, R. Residents' Perspectives on Tourism Impacts of Portuguese World Heritage Historic Centres: Angra do Heroismo and Evora. Tour. Manag. Stud. 2015, 11, 44-51.

15. Hanafiah, M.H.; Jamaluddin, M.R.; Zulkifly, M.I. Local Community Attitude and Support towards Tourism Development in Tioman Island, Malaysia. Procedia Soc. Behav. Sci. 2013, 105, 792-800. [CrossRef]

16. Cottrell, S.; Vaske, J.J. A Framework for Monitoring and Modeling Sustainable Tourism. Rev. Tour. Res. 2006, $4,74-84$.

17. Nunkoo, R.; Smith, S.L.J.; Ramkissoon, H. Residents' Attitudes to Tourism: A Longitudinal Study of 140 Articles from 1984 to 2014. J. Sustain. Tour. 2013, 21, 5-25. [CrossRef] 
18. Pizam, A. Tourism's Impacts, The Social Costs to the Destination Community as Perceived by Its Residents. J. Travel Res. 1978, 16, 8-12. [CrossRef]

19. Rothman, R.A. Resident and Transients: Community Reaction to Seasonal Visitors. J. Travel Res. 1978, 6, 8-13. [CrossRef]

20. Brougham, J.E.; Butler, R.W. A Segmentation Analysis of Resident Attitudes to the Social Impact of Tourism. Ann. Tour. Res. 1981, 8, 569-590. [CrossRef]

21. Davis, D.; Allen, J.; Cosenza, M. Segmenting Local Residents by their Attitudes, Interests and Opinions toward Tourism. J. Travel Res. 1988, 27, 2-8. [CrossRef]

22. Dogan, H.Z. Forms of Adjustment: Sociocultural Impacts of Tourism. Ann. Tour. Res. 1989, 16, $216-236$. [CrossRef]

23. Williams, J.; Lawson, R. Community Issues and Resident Opinions of Tourism. Ann. Tour. Res. 2001, 28, 269-290. [CrossRef]

24. Besculides, A.; Lee, M.E.; McCormick, J. Residents' Perceptions of the Cultural Benefits of Tourism. Ann. Tour. Res. 2002, 29, 303-319. [CrossRef]

25. Andriotis, K.; Vaughan, D.R. Urban residents' Attitudes towards Tourism Development: The case of Crete. J. Travel Res. 2003, 42, 172-185. [CrossRef]

26. Jackson, M.S.; Inbakaran, R.J. Evaluating Residents' Attitudes and Intentions to Act towards Tourism Development in Regional Victoria, Australia. Int. J. Tour. Res. 2006, 8, 355-366. [CrossRef]

27. Chen, C.F.; Chen, C. Residents Attitudes toward Heritage Tourism Development. Tour. Tour. Geogr. 2010, 12, 525-545. [CrossRef]

28. Stylidis, D.; Birah, A.; Sit, J.; Szivas, E.M. Residents' Support for Tourism Development: The Role of Residents' Place Image and Perceived Tourism Impacts. Tour. Mang. 2014, 45, 260-274. [CrossRef]

29. Vargas-Sanchez, A.; Porras-Bueno, N.; de los Angeles Plaza-Mejia, M. Residents' Attitudes to Tourism and Seasonality. J. Travel Res. 2015, 53, 581-596. [CrossRef]

30. Sinclair-Maragh, G.; Gursoy, D.; Vieregge, M. Residents' Perceptions toward Tourism Development: A Factor-Cluster Approach. J. Destin. Mark. Manag. 2015, 4, 36-45.

31. Bagri, S.C.; Kala, D. Residents' Attitudes toward Tourism Development and Impacts in Koti-Kanasar, Indroli, Pattyur Tourism Circuit of Uttarakhand State, India, Revista de Turismo y Patrimonio Cultural. Available online: www.pasosonline.org/articulos/download/file?fid=57.883 (accessed on 3 March 2017).

32. Sinclair-Maragh, G.; Gursoy, D. A Conceptual Model of Residents' Support for Tourism Development in Developing Countries. Tour. Plan. Dev. 2016, 13, 1-22. [CrossRef]

33. Ko, D.-W.; Stewart, W. A Structural Equation Model of Residents' Attitudes for Tourism Development. Tour. Manag. 2002, 23, 521-530. [CrossRef]

34. Lee, T.H. Influence Analysis of Community Resident Support for Sustainable Tourism Development. Tour. Manag. 2013, 34, 37-46. [CrossRef]

35. Mazón, T.; Huete, R.; Mantecón, A. Tourism dependence and host community perceptions. Notes on the social exchange theory. Rev. Encontros Cient. Tour. Manag. Stud. 2009. n.5. Available online: http://www. scielo.mec.pt/scielo.php?script=sci_arttext\&pid=S1646-24082009000100003 (accessed on 3 March 2017).

36. Untong, A.; Kaosa-ard, M.; Ramos, V.; Sangkakorn, K.; Rey-Maquieira, J. Factors Influencing Local Resident Support for Tourism Development: A Structural Equation Model. In Proceedings of the Asia Pacific Tourism Association Conference, Macau, China, 13-16 July 2010.

37. Woosnam, K.M. Using emotional solidarity to explain residents' attitudes about tourism and tourism development. J. Travel Res. 2012, 51, 315-327. [CrossRef]

38. Choi, S.H. The Impacts of Tourism and Local Residents' Support on Tourism Development: A Case Study of the Rural Community of Jeongseon, Gangwon Province, South Korea. AU-GSB J. 2013, 6, 73-82.

39. Peterson, R.A. A meta-analysis of Cronbach's coefficient alpha. J. Consum. Res. 1994, 21, 381-392. [CrossRef]

40. Kline, R.B. Principles and Practice of Structural Equation Modeling, 2nd ed.; Guilford: New York, NY, USA, 2005.

41. Resinger, Y.; Turner, L. Structural equation modelling with LISREL: Application in tourism. Tour. Manag. 1999, 20, 71-88. [CrossRef]

(C) 2017 by the authors. Licensee MDPI, Basel, Switzerland. This article is an open access article distributed under the terms and conditions of the Creative Commons Attribution (CC BY) license (http:/ / creativecommons.org/licenses/by/4.0/). 